eucalypti, wattle, and musk trees, and covered with a dense undergrowth of ferns and creepers, the gullies being filled with tree ferns. Generally speaking there is a noticeable ab ence of game, but at certain seasons the forest resounds with the varied cries of the male lyre bird. The hen builds her nest at the foot of a trunk of a tree, of twigs and bark, lining it with dried ferns and grass, and leaving an opening in the front of the top. Herein she deposits the one egg on which she sits to incubation (for, as an Irish friend said, "she only lays one egg at a time"), leaving the nest daily for food. The country abounds in the hills of ants, from those of the large bull-dog ant, an inch long, to those of a small black variety, and it is upon these insects and their larvæ that the lyre bird chiefly subsists. The bird is of a sooty black colour, with a body somewhat larger than that of a pigeon, but has a tail of graceful form and beautifully marked. Ordinarily, this tail is simply carried behind like a peacock's in repose, but if found upon their "dancing beds" with head erect and tail expanded over the back they are decidedly handsome. These "dancing beds" are patches of comparatively clear ground, from one to two yards in diameter, with the ferns trodden smoothly upon the surface, upon which the birds assemble, and dance and strut to their apparent great delight. The original cry or call of the lyre bird is a very simple one, but his adopted one partakes of that of every sound he hears; for he is a most wonderful mocker, not only of other birds, such as the parrot, cockatoo, yang yang, or magpie, but he will imitate, to the life, the bullock driver with his whip, the step of the teamster's horses, the rasping of the cross-cut saw, and the blows of the axe and tomahawk, and more wonderful still, more than one of these at the same time, so that the solitary explorer is led to believe he has suddenly come upon pioneers of civilisation in the heart of the forest.

The male bird is exceedingly pugnacious, and this fact is made use of by the settlers to his destruction, for his tail is worth \$3. By imitating one of his prominent calls, the hunter can lure him within gun-shot, although naturally very shy; he comes to repel a fancied intruder into his domain. His flesh is very dark-coloured and coarse, and only used as food in cases of necessity. Many attempts have been made to rear the birds in captivity, and there is a report that one has been successful. With this exception, which I cannot authenticate, I never heard of any result but failure.

The sound of his call so alters in proportion as his tail is in full feather or indifferently ornamented, that hunters can judge from that whether or no any individual bird is worth pursuit.

My apology for asking for so much of your valuable space must be in the fact that until I set myself the task of getting the above information, I could not obtain it from published accounts.

Railway Survey Camp, Manaro, New South Wales, ALFRES MORRIS September $\mathbf{I}$

\section{Blackberry Blossoms in November}

I HAVE this day seen blackberry blossoms in a hedge on this road, and yet the autumn has been rainy and inclement.

Osborne Park, Belfast, November to JOSEPH JOHN MURPHY

\section{EXPLORATIONS IN PAHANG}

PAHANG is a smatl state in the Malay peninsula on the eastern side of the dividing range, with a coastline on the China Sea. The territory is almost exclusively occupied by Malays, who live on the banks of the rivers; but in the unexplored forests of the interior near the mountains there are a few tribes of wild aboriginal Sakeis. Though Pekan, the capital, is not quite 200 miles from Singapore, it is rarely visited by Europeans. It is situated at the mouth of the river Pahang, and on this stream the bulk of the population is to be found. The Pahang is the main artery of communication with the interior. Its course is inaccurately laid down on the map published by the Straits Government in 1879 . Quite recently, however, Mr. W. Cameron, a surveyor, has by his own efforts, unassisted by the Government, mapped the whole course of the stream, and his map, not yet published, is in the hands of the Straits branch of the Royal
Asiatic Society. Recently also the river w:s ascended by Mr. G. Scaife. He went up by the Semanten River and one of its tributaries to the dividing range, and then, accompanied by Malays only, he crossed to Klang, in Selangor, in three days, and so reached he western coast. In May of this year Mr. Swettenham, the Government Resident in Selangor, succeeded in passing the dividing range from Perak by ascending the River Slim. Having descended on the eastern side of the mountains he reached the Lipis River, down which he came on rafts to the Pahang, and so on to Pekan. The whole journey occupied one month.

It may seem strange that a territory so near Singapore should be so little known. The reasons for this are that on the land side its jungles and forests are very inaccessible, and that for six months of the year, when the north-east monsoon is blowing, the rivers and coast-line can scarcely be approached from the sea. Pabang has always had a peculiar interest because of the large and rich gold mines said to exist within its limits. Curious specimens of nuggets are constantly reaching the British settlements from this locality.

In July last I started from Singapore with the intention of seeing some of the gold fields and generally to examine the geology of the river and some of its tributaries. I was accompanied by Mr. H. G. James and Mr. Scaife. A small steam launch had been sent on previously, and we hoped by its means to save time and the inconvenience of depending on native boatmen.

Peizan, the capital, lies about six miles above the mouth of the river. It is a small town of perhaps 1500 inhabitants. It is well laid out in rectangular grassy streets. The sicles of these are formed of high bertane fences, within which, buried in tropical foliage, are the detached bungalows of the inhabitants; the houses are built high off the ground with attop roofs. There is one street of wretched Chinese shops called the market. In the midst of this is a somewhat pretentious two-story palace for the Sultan. Close by are many sheds built for games for royal diversion, amid which is a conspicuous inclosure covered in, where for many hours almost daily his Highness plays at top-spinning with his nobility and gentry.

He received us courteously at midnight (a common hour for receptions) and seemed quite pleased to have his country visited by Europeans. He gave us a letter commanding all chiefs (Datus) to give us any help we might require. He does not affect any royal splendour, but is very simple in his habits. He is a liberal-minded man, who might do much but for his indolence.

We started with a party of thirteen in a large river prahm, in case the launch should fail us, which it promptly did. Though only drawing 2 feet 8 inches we lost four days in advancing fifteen miles. At last the shallows stopped us altogether, and we had to take to the prahm. The Pahang drains an immense basin and is fed by innumerable tributaries, so that it is rather disappointing to find that unless in times of flood it is only navigable for the small prahm of the Malay. The largest of these scarcely draws two feet of water.

The channel is from 300 to 600 yards wide, interrupted continually by jungle islands and large sandbanks. On the latter pea-fowl (Pavo javanicus) are commonly seen. The banks are lined at intervals with small villages. 'They may be known at a distance by the clumps of cocoanut and betel palm. On our approach we frequently heard the wooden gong or drum echoing with singular clearness through the forest. It reminded one of what Stanley tells us of the River Congo, except that the Pahang natives are very peaceable. The vegration was of the usual Malay character. The common trees were Ficus, Phyllanthus, Vitex, Castanopsis, Garcinia, Dipterocarpus, Fagrea, Hibiscus, \&c., with creepers and vines innumerable, especially Batuhinia, Vitis, Ipomæea, Entada, 
and Mucina. I saw very little that was new to me, but there was no time for any search. At forty miles we came to the River Lint, which at one time had a great reputation: for its gold mines. Two Europeans have started to prospect the locality. We met with them on our return. They had found traces of very extensive workings in former times, but the whole are quite abandoned. The country around is hilly, and the banks of the river are beautifully picturesque. Scarcely any natives live in the vicinity.

We passed many small tributaries to the right and left, and at ninety-one miles, or eight days, from Pekan passed the Semanten, a large affluent coming from the west. Our course had been west hitherto, but now turned to the north-west. Our progress was but slow. We had hired a second boat, and both had to be urged against a strong current by means of long polesthe usual mode of up-stream progress in the Malaysia. One seldom averages more than a mile an hour in this way.

At about I 30 miles we passed the Tomoleng, a large stream to the right. It was up this, I believe, that Baron Maclay passed in 1875 . The river to the left is called the Jelis or Jelai. Between the two there is a very small stream which is called the Pahang. In Cameron's map the Jelai is marked as the Pahang, but the natives do not call it so. The Jelis is still a fine river, with fewer sandbanks, and I think a deeper bed. Fifty miles further we reached the Lipis. Where we left the Jelis it was still an important stream at least 200 yards wide. The Lipis is also a good stream, half the width of the former. We only went about ten miles up it, and at that distance or less came to Punjom, a large village, the second in importance to Pekan. We found that the cholera had just visited the place, and carried off half the inhabitants, and we found subsequently that several other villages had been visited, or were actually suffering from this terrible epidemic.

About three miles from Punjom is a celebrated gold mine at a village called Jelai, which has been worked for centuries. The formation is just like what is seen in the auriferous districts of Australia-that is to say, highly inclined slate schists and sandstones with quartz lodes containing the gold. The mines, I am told, have been worked in succession by Siamese, Malays, and Chinese. At present about thirty Chinese are employed, with a few Malays, who wash the sands for gold dust. The locality is very curious, from the evident antiquity of the workings. An enormous quantity of material has been quarried away, and shafts have been sunk in the solid rock. Subsequently the rock has been removed, leaving traces of the shafts on the faces of the quarries. It seems as if the miners had found gold in the alluvium, and then had removed the rock in searching for more. The lodes were scarcely touched, probably being too hard. But just beside the lodes the casing with some pockets of pyrites have been taken out in small quantities and are still worked. Doubtless these ores are rich, but a small quantity of free gold dust is all that these miners get.

The ground for acres around is covered with refuse heaps, and after each rainfall the native women and children may be seen searching for specks of gold in the sand. There is a good deal of iron pyrites in the heaps, and as this gradually decomposes, the gold is liberated in the form of fine dust. The mine is about to be worked by a European company.

I returned from Punjom down the Pahang as far as the Semanten, and ascended that river almost due west for about 50 miles. It then forks into the Karau (W.N.W.) and the Brentong (S.W.). As the latter was a series of rapids we changed our boats for small canoes. The water is very deep in places, but shallow at the rapids, where it falls over barriers of beautiful black marble with white veins, or over slate rocks, highly inclined and much jointed. It took us a whole day to ascend about 15 miles, as there was a fresh in the stream. This made the work of poling up the rapids difficult and exciting. After the first few miles we saw no habitations, but we met small bamboo rafts carrying down ingots of tin from the village of Brentong. The river flows in a channel about 50 yards wide, through a dense forest echoing with the cry of the large black siamang or gibbon monkey (Hylobates syndactylus?). Occasionally we heard the peculiar warning shriek, as I may call it, of the wild aboriginal Sakei.

We left our canoes at the junction of a mountain torrent called the Dua. Here we camped one night, and then crossed to the sources of the stream, passing over several high mountain spurs from the main divide. In the mountains we found a few Malays washing stream tin from a shallow, coarse gravel. This consisted of broken Palæozoic slates and sandstones. We visited two or three mines of this kind in various places in the ranges. Travelling was very difficult, because of the undergrowth amid a fine forest of Dipterocarpus, oak, chestnut figs, Dammar, Fagræa, \&c., with much Bertam palm (Huguessonia). Traces of tigers and elephants numerous. Game plentiful. In the river a very large barbel and a smaller one abundant (Barbus burmanicus and Kolus?), both tasteless fishes and full of bones. We found also an eellike voracious fish, which I took to be Ophiocephalus micropeltes, excellent eating, but uncommon. I have found the same fishes in all the mountain rivers of the Malay peninsula.

We returned direct to Pekau from the Sungei Dua, having spent about five weeks in the boats. Throughout we found the people affable and courteous, not timid of strangers, though some of them had never previously seen white men. Their only medium of exchange is a tin coinage, shaped for the most part like an old-fashioned square inkstand. They objected to receive the smaller silver coin of the Straits Settlements, but would take an empty bottle or a meat or biscuit tin in exchange for a fowl, and fruit such as bananas, cocoa-nuts, mangostems, and papaws, besides tapioca, maize, and brinjals.

We saw a few slaves, who seemed to be Sakeis or Africans. The whole population of the State can scarcely be 50,000 , of which probably not 500 are Chinese.

About half way between the dividing range and the sea there is a belt of detached conical steep mountains I 500 to 2000 feet high. From the specimens of rock abutting on the River Pahang I judge these hills to be volcanic, and to consist of trachytic and felspathic rocks. I also found in the bed of the stream isolated patches of andesite, felsite, molaphyre, and limestone. In respect to the volcanic rocks the eastern side of the Malay peninsula differs much from the western.

Singapore, August 28

J. E. TENISON-WOOD

P.S. - I have just seen in a number of NATURE, published in the early part of this year, a letter from $\mathrm{Mr}$. L. Wray, jun., correcting what he considers certain mistakes of mine. It is due to your readers to state that I do not accept any of these corrections. During the long period that I have spent in exploring in these regions, Mr. Wray travelled with me for about a fortnight. I should like to repeat that I have never seen on the Malay peninsula any sign of upheaval or subsidence. The instance Mr. Wray refers to at Matang obviously admits of a very different interpretation.

\section{THE CRETACEOUS FLORAS OF CANADA Geological Relations of the Floras}

I $\mathrm{N}$ a memoir published in the first volume of the Transactions of this Society I have given a table of the Cretaceous formations of the western North-

' By Sir William Dawson, F.R.S., \&c. From advance sheets of a memoir to appear in the Transactions of the Royal Society of Canada. 